University for Business and Technology in Kosovo

UBT Knowledge Center

UBT International Conference

2018 UBT International Conference

Oct 27th, $10: 45$ AM - 12:15 PM

\title{
Optimization of the ground for CAB 6P (Prunus cerasus)
}

\author{
Avdirrahman Gashi \\ Agricultural University of Tirana, avdi-gashi773@hotmail.com \\ Sami Gashi \\ University for Business and Technology \\ Taulant Mitrushi \\ In Vitro Laboratory Elbasan \\ Edlira Kukali \\ Agricultural University of Tirana
}

Follow this and additional works at: https://knowledgecenter.ubt-uni.net/conference

Part of the Food Science Commons

\section{Recommended Citation}

Gashi, Avdirrahman; Gashi, Sami; Mitrushi, Taulant; and Kukali, Edlira, "Optimization of the ground for CAB 6P (Prunus cerasus)" (2018). UBT International Conference. 184.

https://knowledgecenter.ubt-uni.net/conference/2018/all-events/184

This Event is brought to you for free and open access by the Publication and Journals at UBT Knowledge Center. It has been accepted for inclusion in UBT International Conference by an authorized administrator of UBT Knowledge Center. For more information, please contact knowledge.center@ubt-uni.net. 


\title{
Optimization of the ground for CAB 6P (prunus cerasus)
}

\author{
Avdirrahman Gashi ${ }^{1}$, Sami Gashi $^{2}$, Taulant Mitrushi $^{3}$, Edlira Kukali $^{4}$ \\ ${ }^{1 *}$ Faculty of Agricultural \& Environment, Agricultural University of Tirana \\ \&Faculty of Agricultural \& Environment, Agricultural University of Tirana, \\ ${ }^{2}$ Faculty of food \& Biotechnology, University for Busines und Technology of \\ Prishtina. \\ ${ }^{3}$ In Vitro laboratory Elbasan. \\ ${ }^{4}$ Faculty of Agricultural \& Environment, Agricultural University of Tirana \&Faculty \\ of Agricultural \& Environment, Agricultural University of Tirana. \\ avdi-gashi773@hotmail.com,sami.gashi@ubt-uni.net
}

\begin{abstract}
Rooting is a process that is induced by many difficulties, especially in fruit trees. For this reason, four nutrient terrains that contain different concentrations of auxin ANA $(\alpha-$ naphthaleneacetic acid), BAP, GA3 and macro and micronutrient MSs are compared. Rizogenesis is observed after three to four weeks of cultivation on the ground of rupture. Explants react differently in each field used (Figures 4,5,6,7). The concentration of inorganic and auxinous ANA salts on the nutrient terrains affects the rooting index and the characteristics of the roots.Plants of the prunuscerasium L species showed better results during rooting cultivation I, where the rooting index was very high (90\%), while in rooting field II (75\%) (Mirrors, Graphs a, b).In the latter case (the rooting ground III), the high concentrations of ANA auxin induce the formation of the colon at the end of the stem in the CAB 6P herb. In this case, the number of roots is high, but they have an abnormal appearance, as they are too short and thick (Fig. B). The variance analysis (ANOVA), during the rooting stage of the four types of rootstocks, confirms some changes with respect to rooting index in each field (Table 3, Chart 1a, b). Based on the Variance Analysis Table $(\mathrm{P}<0.05)$, since the value $\mathrm{F}$ is much greater than the theoretical value (Prob> F) then there is a statistical difference in the comparative data.
\end{abstract}

\section{Introduction}

The biotype of PrunusCerasus (CV Maraska di vigo) developed by the University of Bologna is used as a rootstock for cherry as well as for sour cherry. It is middle-class productivity the rootstock, the best results are achieved with a T-bar or a sleeping chip. Cherry compatibility with this rootstock is very good, while the variety of Sour Cherry has excellent compatibility. It has a moderately developed root system, adapts to heavy soils with low perspiration while resistance to limestone reaches up to $9 \%$ of active lime. It is sensible by Armellariamellea and solid from phytophoracactorus and Verticillumi.

The varieties of cherries, grafted in this rootstock have a time of blooming and maturing for 2-3 days earlier than those grafted in the seedbed. Fruits are of good quality and of optimal size. It is a suitable rootstock for specialized cherry orchards where the number of herbs must reach 500800 plants per hectare. 


\section{Nutrition terrain selection}

Choosing a particular field depends on plants specifics, tissue or organ in culture and the purpose of culture. Success depends on knowing the nutritional needs of the tissues. As a universal ground for the start of the callus from the dicotyledonous tissues is considered the terrain BazalMurashige and Skoog (MS). Its characteristic is the relatively high concentrations of nitrates, potassium and ammonium (George, 1993).

The mineral composition of the terrain has been studied as an important factor affecting in vitro addition of the 'Gisela 5 ' from Ružić et al. (2000) that received a better growth and development in MS and MS $\times 2$ than $1 / 2$ MS and $1 / 4$ MS.

Šiško (2011) reported that the WPM terrain shows the highest degree of addition (4.2 explants) in the 'Gisela 5', while MS with lower values (3.0 explants).

Bošnjak Et al. (2012) successfully added 'Gisela 5' to the Quorin and Lepoivre - QL terrain (1977).Terrain DKW medium contains $0.5 \mathrm{mg} \cdot 1-1$ BAP was used for slow augmentation of Gisele (Lambardi et al., 2006).

Dorić et al. (2014) used this field In vitro addition of various cherry subgroups, including 'Gisela 6'. Although MS is still more widely used, it is often replaced with low salt concentration, especially those with lower nitrogen content, including ammonium nitrate content, which is 1650 mg 1-1 in MS and 1416; $400 \mathrm{mg} \mathrm{1-1} \mathrm{in} \mathrm{DKW} \mathrm{and} \mathrm{WPM.}$

In Vitro Addition remains a priority since the phytosanitary situation is of paramount importance in the production of new uninfected cultivars. Regarding the spread of viruses in fruit trees, appearing in many recent publications, prunus tree tests in Albania reveal that $42 \%$ of the tested trees are infected with at least one virus. Cherries and plums are the most infected species, with $56 \%$ and $47 \%$ respectively

Treatment of seeding materials of fruit trees with the use of in vitro meristemic methods for the elimination of viruses for important species of Prunus, Malus and Pyrus grown in Albania and Kosovo remains to be a future challenge. That's why I have the ambition to bring successful results, in researching the objectives and develop a successful method for Kosovo which does not have a micro propagation laboratory.

\section{Nutritional grounds}

The success of "in vitro" culture depends heavily on the chemical composition of the field of culture. For the optimal plant growth, it is necessary the presence of relatively large quantities of macro elements, small quantities of microelements, iron supply, carbohydrates, vitamins and especially phytohormones.

\section{Microelements}

Plant tissue cultures require continuous supply of some inorganic salts. Essential elements are N2, K, Ca, Mg and S (Table 3) (Taiz\&Zeiger, 2006), Nitrogen, Phosphorus, Magnesium, Sulfur Potassium, Calcium, etc. Many authors present 5-9 microelements in the form of sulphates or chlorides as indispensable in very small quantities (usually several $\mathrm{mg} \mathrm{1-1)}$ ). The most prominent and most present in the nourishing culture are $\mathrm{Mn}, \mathrm{Zn}, \mathrm{B}, \mathrm{Cu}, \mathrm{Co}, \mathrm{J}$ and $\mathrm{Mo}$ (Mirror 3).Agar is also a source of many microelements, it has traces of vitamins, and possibly toxic substances (Pierik, 1988).

\section{Phytohormonesand growth regulators}

From culture tissue often is required a combination of other ausines and phytohormones.. The term "phytohormone" is reserved for natural plant hormones. Growth regulators are called synthetic as 2,4-D (dichlorophenoxyacetic acid) or kinetin (Salisbury \& Ross, 1992). Phytohormones and growth regulators are used in very small quantities, ranging from 0.01 to 10

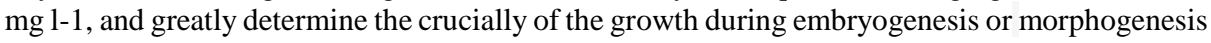


(Tech \& Seiler, 2004). But their use in the nourishing ground depends mainly on the type of the plant and plant species and by endogenous phytohormones. Mainly three phytohormone categories are used:

\section{Auxines}

It plays a role in cell growth and division, differentiation of encephalopathy, different bones and roots tropisms, fruit growth etc. In tissue cultures, austenas are used to stimulate the growth of boulders, start initiation of roots and extension, induction of somatic embryogenesis and the onset of the kallus formation. Auxin causes tissue swelling and stiffens the formation of roots in high concentrations. (Tech \& Seiler, 2004).

Among the natural austencies, indolacetic acid (AIA) is used in culture. 3-indol butyric acid (AIB) are highly effective. AIB is the root-rooting agent. Naphthylacetic acid (ANA) and dichlorophenoxyacetic acid (2,4-D) are synthetic auxin. 2,4-D is the most effective auxin for callus proliferation but is used in very small quantities, 10-7-10-5 $\mathrm{M}$, as it is highly toxic (Satyavathi et al., 2004; Taiz\&Zeiger, 2006).

\section{Cytokine}

They are used to stimulate plant growth and development, because they favour cell division, cytokinesis and callus organization, especially when combined with austenas. Cytokinins are involved in cell division, morphogenesis, the onset of the formation of shoots, affecting apical dominance, and so on. (Tech \& Seiler, 2004). Of the cytokines, most useful in the soil is kinetin (6-furfurylaminopurine), BAPP or BAP (6-benzylaminopurine or 6-benzyladenine) and zeatin. The first two are synthetic, while zeatin is natural (Taiz\&Zeiger, 2

\section{Gibereline}

Not widely used in "in vitro" culture, but GA3 (gibberellic acid) seems to be more usable. After autoclaving, its activity loses $90 \%$. Generally, gibberellins induce protuberance and increase the merits or buds. They also interrupt the deep sleep of embryos or isolated seeds (Tech \& Seiler, 2004; Taiz\&Zeiger, 2006).

It should be noted that the ausine / cytokine ratio is an instrument in regulating cell division, prolongation, cell differentiation, and organ formation. In general, low concentrations of auxin and high levels of cytokines stimulate cellular growth.

Some cultures are capable of rapidly hormones forming in an autotrophic way after several recurrent subcultures. The advantage of using these tissues is the high intensity of their growth and the low cost of the field without phytohormone.

Also, in some cases, no phytohormone is used on the ground eg. in the "in vitro" genetic banks, when vegetative material is kept in a state of minimum growth for several months to a year (Kongjika et al., 1998) or during subcultures when cultures have been developed in-vitro, have sucked sufficient amount of phytohormones during the first stages of development (Kongjika et al., 1995).The PH is normally adjusted between 5.5 and 6.0 before autoclaving, but varies during autoclaving and during the culture period.

\section{Material and Method}

When the implants reached lengths of 2 to $4 \mathrm{~cm}$, they were transferred to the rooting ground. Three variants of terrains were analyzed with auxin supplements ANA, BAP, IBA and GA3 during root formation : 
$\neg 1 / 2$ MS macroelement, MS microelements, MS vitamins combined with 0.1 mg 1-1 ANA; $\neg 1 / 2$ MS macroelement, MS microelements, MS vitamins combined with $0.1 \mathrm{mg} 1-1$ ANA; $\neg$ MS macroelement, micro-element $1 / 2$ MS, MS vitamins combined with 2 mg 1-1 ANA; $\neg$ MS macro-elements, micro-nutrients $1 / 2$ MS, MS vitamins combined with BAP 0.3mg.l-1, IBA $0.1 \mathrm{mg}^{-1}, \mathrm{GA}-36.7 \mu 1$

For $\mathrm{CAB} 6 \mathrm{P}$ rootstock there is no reference in the microscope but only for gyrus 6 , for which the references emphasize that with an increased percentage of IBA in MS we have a successful root formation.

In Experiment II we tested with IBA but the result was not significant

The rooting response was evaluated after 4-5 weeks of cultivation on each rooting ground. In all the fields, the $\mathrm{pH}$ is specified at the value of 5.6 and sucrose and agar is added respectively to $30 \mathrm{~g} 1-1$ and $3 \%$.

Table 1. Nutritional sites and concentrations of synthetic hormones added to them (R1, R2, R3 and R4)

(R I)

\begin{tabular}{|l|l|l|}
\hline Microelements $1 / 2$ & & $25 \mathrm{ml}$ \\
\hline Microelement & & $50 \mathrm{ml}$ \\
\hline Fe-EDTA & & $5,0 \mathrm{ml}$ \\
\hline Vitamin & & $10 \mathrm{ml}$ \\
\hline ANA & $\mathbf{0 , 1} \mathbf{m g} . \mathrm{l}^{\mathbf{- 1}}$ & $\mathbf{0 , 0 5} \mathbf{m g}$ \\
\hline Sucrose & $30 \mathrm{~g} . \mathrm{l}^{-1}$ & $15 \mathrm{gr}$ \\
\hline Agar & $6,7 \mathrm{~g} . \mathrm{l}^{-1}$ & $3,35 \mathrm{~g}$ \\
\hline Ph. & 5,6 & \\
\hline (R 2) & & \\
\hline
\end{tabular}

\begin{tabular}{|l|l|l|}
\hline Microelements & & $50 \mathrm{ml}$ \\
\hline Microelement $1 / 2$ & & $25 \mathrm{ml}$ \\
\hline Fe-EDTA & & $5,0 \mathrm{ml}$ \\
\hline Vitamin & & $10 \mathrm{ml}$ \\
\hline ANA & $\mathbf{0 , 1 \mathbf { m g } . \mathbf { l } ^ { - 1 }}$ & $\mathbf{0 , 0 5} \mathbf{m g}$ \\
\hline Sucrose & $30 \mathrm{~g} \cdot \mathrm{l}^{-1}$ & $15 \mathrm{gr}$ \\
\hline Agar & $6,7 \mathrm{~g} . \mathrm{l}^{-1}$ & $3,35 \mathrm{~g}$ \\
\hline Ph. & 5,6 & \\
\hline
\end{tabular}

(R 3)

\begin{tabular}{|l|l|l|}
\hline Microelements & & $50 \mathrm{ml}$ \\
\hline Microelement $1 / 2$ & & $25 \mathrm{ml}$ \\
\hline Fe-EDTA & & $5,0 \mathrm{ml}$ \\
\hline Vitamin & & $10 \mathrm{ml}$ \\
\hline ANA & $\mathbf{2 , 0 \mathbf { m g } . \mathrm { l } ^ { - 1 }}$ & $\mathbf{2 , 0 m g}$ \\
\hline Sucrose & $30 \mathrm{~g} . \mathrm{l}^{-1}$ & $15 \mathrm{gr}$ \\
\hline Agar & $6,7 \mathrm{~g} . \mathrm{l}^{-1}$ & $3,35 \mathrm{~g}$ \\
\hline
\end{tabular}




\begin{tabular}{|l|l|l|}
\hline Ph. & 5,6 & \\
\hline
\end{tabular}

(R 4)

\begin{tabular}{|l|l|l|}
\hline Microelements & & $50 \mathrm{ml}$ \\
\hline Microelement $1 / 2$ & & $25 \mathrm{ml}$ \\
\hline Fe-EDTA & & $5,0 \mathrm{ml}$ \\
\hline Vitamin & & $10 \mathrm{ml}$ \\
\hline BAP & $\mathbf{0 , 3 m g . l ^ { - 1 }}$ & $\mathbf{0 , 1 5 m l}$ \\
\hline IBA & $\mathbf{0 , 1} \mathbf{m g} . \mathrm{l}^{-1}$ & $\mathbf{0 , 0 5 m l}$ \\
\hline GA-3 & $\mathbf{6 , 7 g . l ^ { - 1 }}$ & $\mathbf{0 , 1 5 g m l}$ \\
\hline Sucrose & $30 \mathrm{~g} / 1^{-1}$ & \\
\hline Agar & $3,35 \mathrm{~g}^{--}$ & \\
\hline Ph. & 5,6 & \\
\hline
\end{tabular}
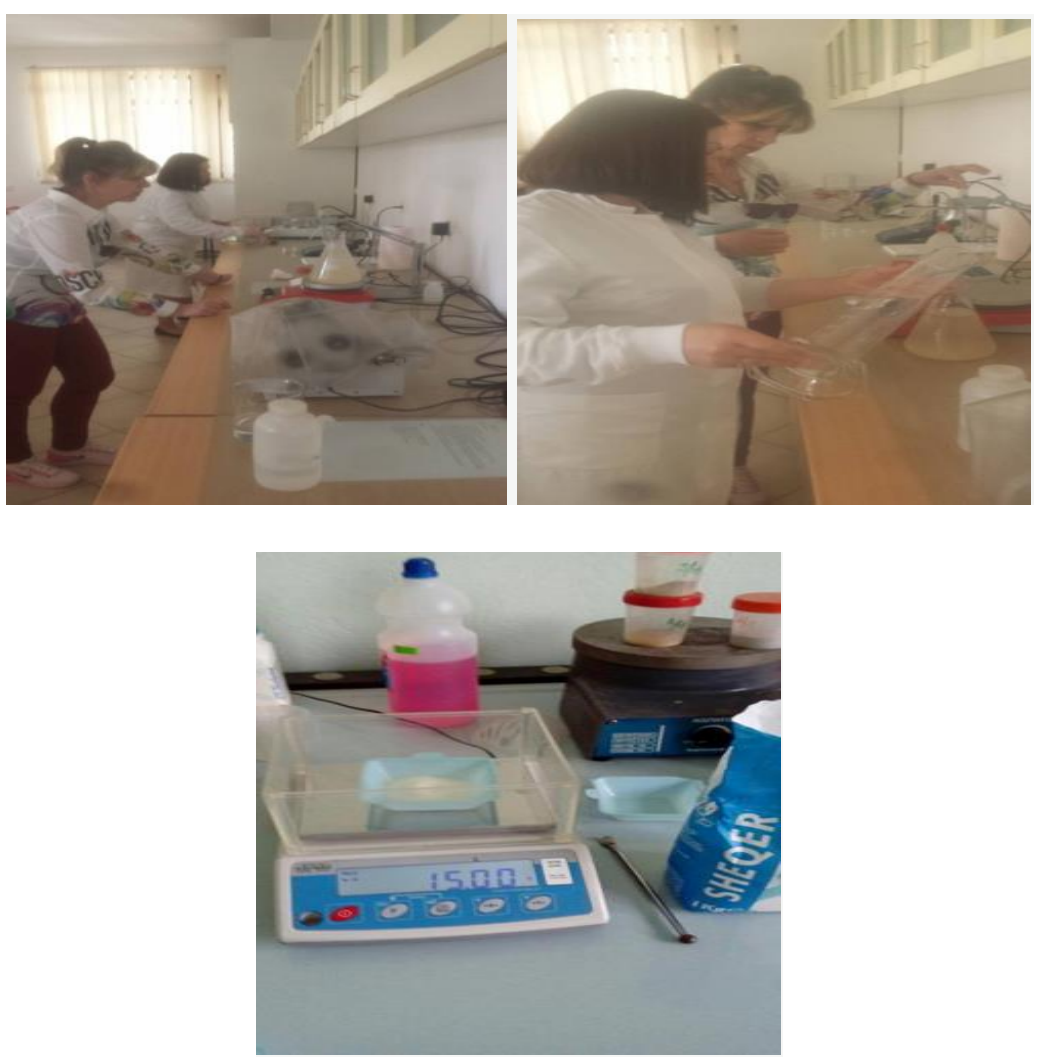

Figure $1(\mathrm{a}, \mathrm{b}, \mathrm{c}) . \mathrm{a})$ Field preparation b) Micro- macro elements and weighing c) $\mathrm{PH}$ adjustment. 


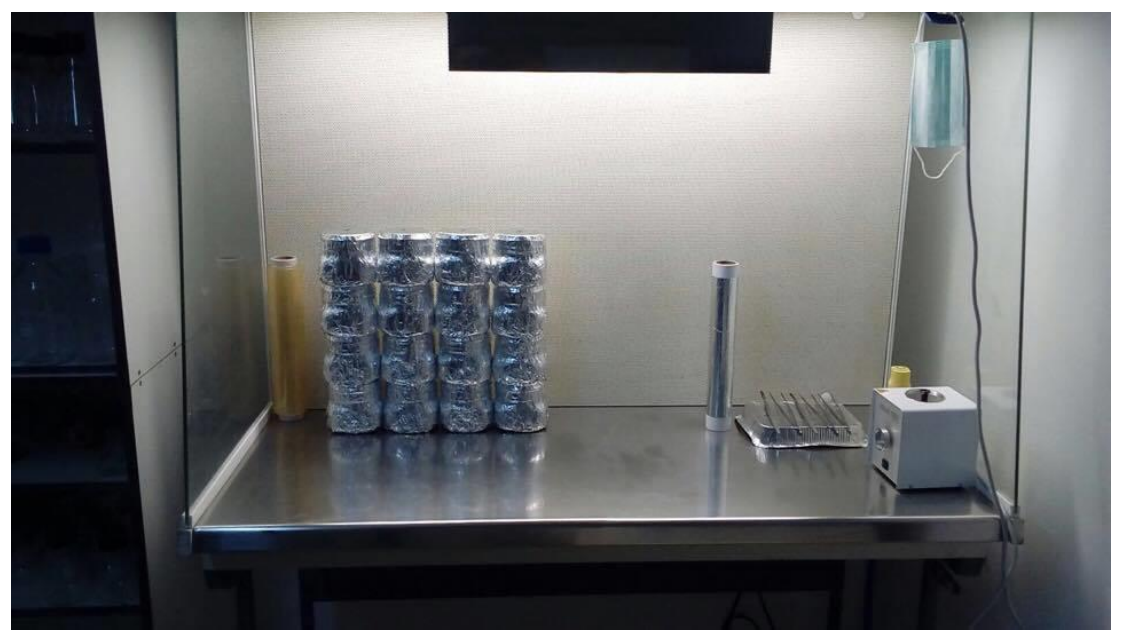

Figure 2. Laminar flushes before the initiation of inoculation for root-formation, stinging sterilizers.

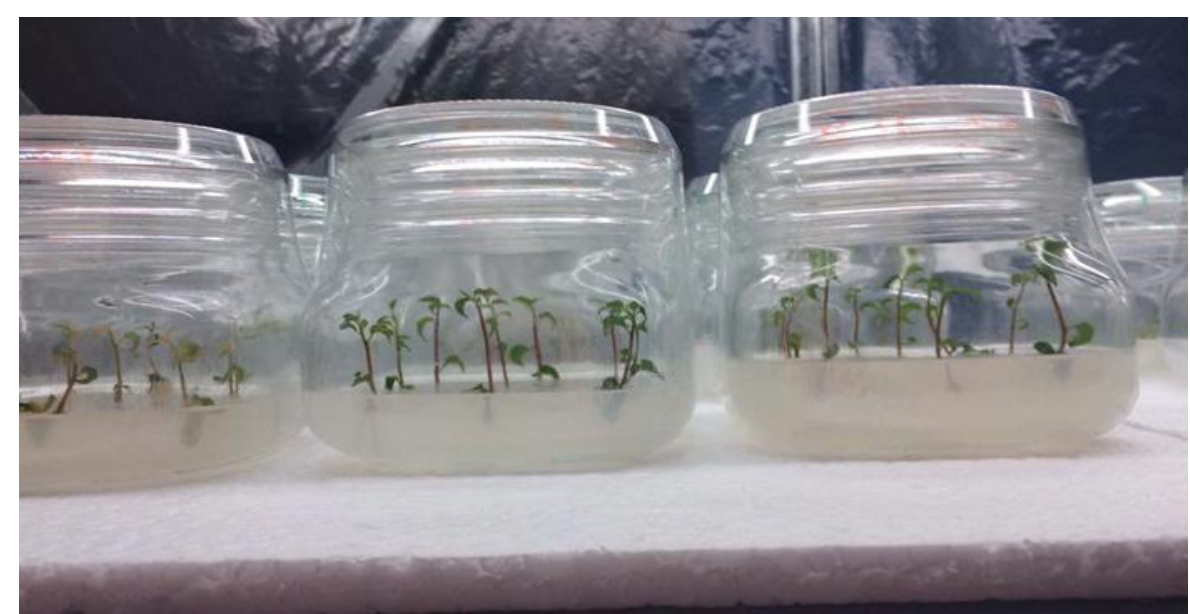

Figure 3. Laminar flushes before the initiation of inoculation for root-formation, stinging sterilizers. 


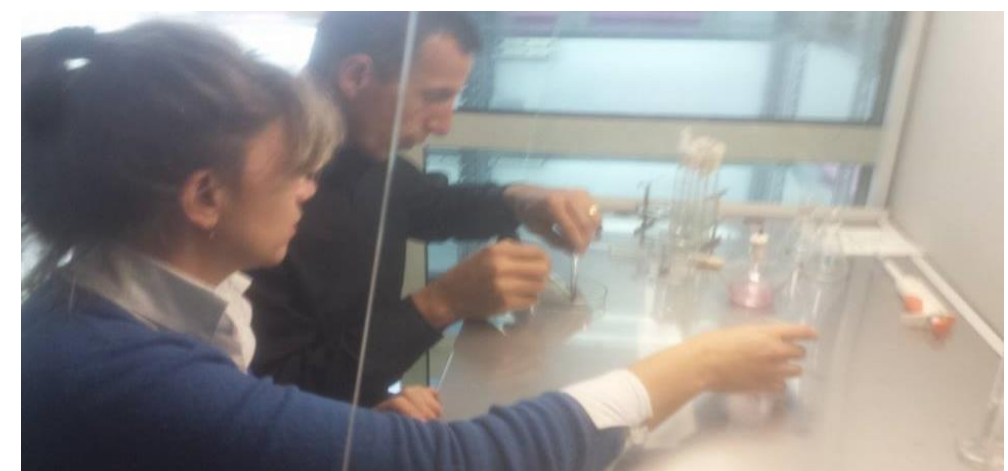

Figure 4. Plants at the stage of root formation in the laboratory, vegetation rooms of P. avium L.

\section{Results and Discussion}

Rooting is a process that is induced by many difficulties, especially in fruit trees. For this reason, four nutrient terrains that contain different concentrations of auxin ANA ( $\alpha$-naphthaleneacetic acid), BAP, GA3 and macro and micronutrient MSs are compared.

Rizogenesis is observed after three to four weeks of cultivation on the ground of rupture. Explants react differently in each field used (Figures 4,5,6,7). The concentration of inorganic and auxinous ANA salts on the nutrient terrains affects the rooting index and the characteristics of the roots.Plants of the prunuscerasium $\mathrm{L}$ species showed better results during rooting cultivation I, where the rooting index was very high $(90 \%)$, while in rooting field II (75\%) (Mirrors, Graphs a, b).

In the latter case (the rooting ground III), the high concentrations of ANA auxin induce the formation of the colon at the end of the stem in the CAB 6P herb. In this case, the number of roots is high, but they have an abnormal appearance, as they are too short and thick (Fig. B). The variance analysis (ANOVA), during the rooting stage of the four types of rootstocks, confirms some changes with respect to rooting index in each field (Table 3, Chart 1a, b). Based on the Variance Analysis Table $(\mathrm{P}<0.05)$, since the value $\mathrm{F}$ is much greater than the theoretical value (Prob> F) then there is a statistical difference in the comparative data. 


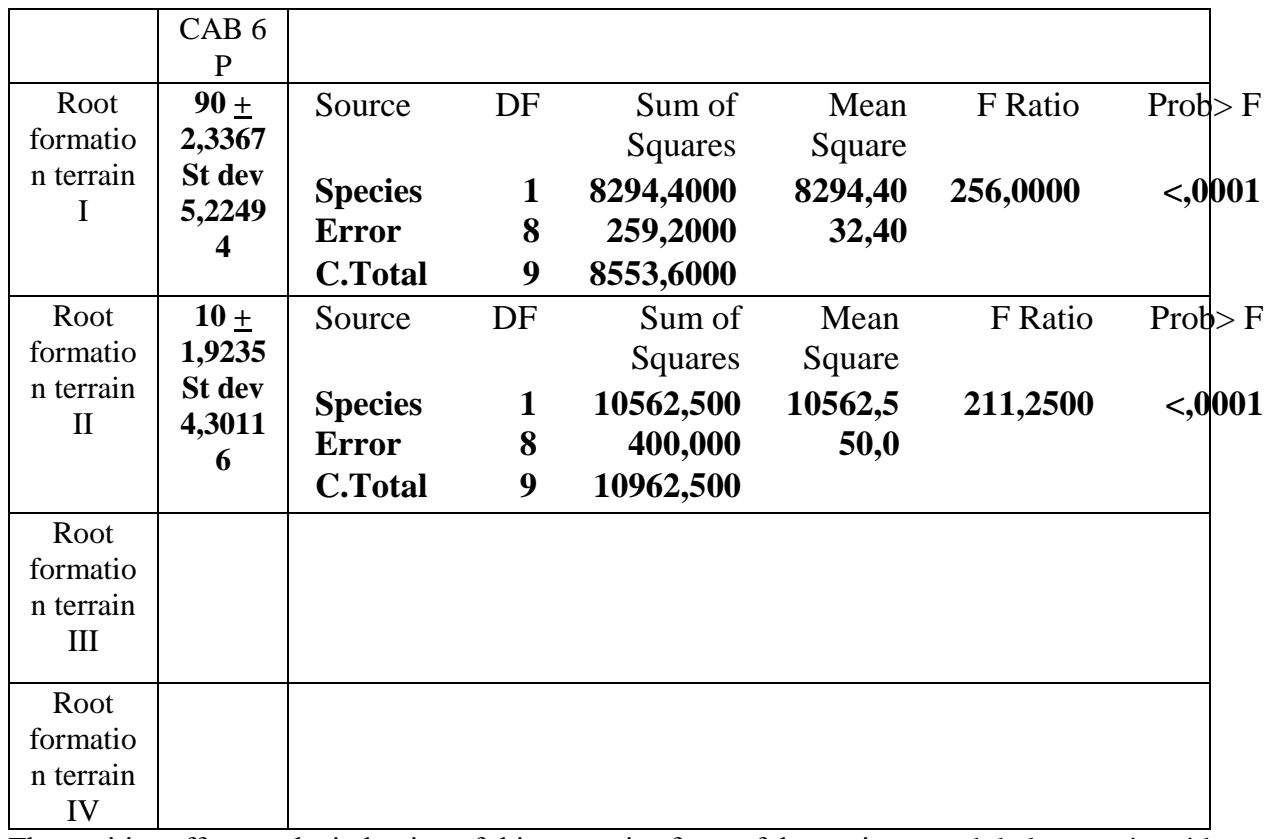

The positive effect on the induction of rhizogenesis of one of the auxin, $\alpha$-naphthaleneacetic acid (ANA), has been reported in several authors' studies in the in vitro fertilization of apple (Nemeth, 1981, Monter, 1992). Comparison of different terrains showed that the use of high concentrations of auxin (2-3 mg 1-1) favours the formation of the callus and limits the growth of the roots. Also in other studies with P. avium species (Shatnavi et al., 2007), the same phenomenon was observed using ruminant hormones (AIB, ANA and AIA). As a result, it is recommended to use in lower than $0.5 \mathrm{mg} 1-1$ doses.

\section{Conclusions}

Based on this research we have reached to the following conclusions:

1. The "in vitro" (microshum) culture of the Prunusavium species results as an efficient method for the propagation of these plant species;

2. P. exteries exhibit better results during the rooting cultivation I containing $1 / 2$ MSmacroelements, MS microelements, MS vitamins combined with 0.1 mg 1-1 ANA;

3. P. aviumexteries exhibit better results during the Rooting II cultivation that contains $1 / 2 \mathrm{MS}$ macroelement, MS $1 / 2$ microelements, MS vitamins combined with $0.1 \mathrm{mg}$ 1-1 ANA; 4. The in-vitro (microshummium) culture of Prunuscerasium species results as an efficient method for propagating this species plant.

5. During the direct organogenesis of the organized systems results in a high micro-shrinkage coefficient (6-7 bushes) and thus it is possible to obtain a large number of herds after some subcultures.

6. High rooting index $(75 \%)$ is observed using the first tested variant of the feeding environment. This variant also represents the highest percentage of survival (73\%).

7.Problematic is a very low index of acclimatization for which the next work will be done. 


\section{References}

1. Augusto C.S.S. 2001. Micropropagação de amoreirapreta cv. Brazos.Dissertação, MestradoemProdução Vegetal, Universidade Federal do Paraná, Curitiba, Paraná, Brasil 30: 266-270.

2. Bošnjak A.M., Kereša S., Jerčić I.H., Barić M. 2012. The effect of cytokinin type and explant orientation on axillary shoot proliferation and in vitro rooting of 'Gisela 5' cherry rootstock. Journal: Food, Agriculture and Environment 10(3\&4): 616-620.

3. Clapa D., Fira A., Joshee N. 2013. An efficient ex vitro rooting and acclimatization method for horticultural plants using float hydroculture.HortScience 48(9): 11591167.

4. Dimassi-Theriou K. 1995. In vitro rooting of rootstock GF 677 (P. persica $\times$ P. amygdalus) as influenced by mineral concentration of the nutrient medium and type of culture-tube sealing material. Journal of Horticultural Science \& Biotechnology 70(1):105-108.

5. Dorić D., Ognjanov V., Ljubojević, M., Barać G., Dulić J., Pranjić A., Dugalić K. 2014. Rapid propagation of sweet and sour cherry rootstock.NotulaeBotanicaeHortiAgrobotanici Cluj-Napoca 42(2): 488-494. DOI: 10.15835/nbha.42.2.9671.

6. Fotopoulos S., Sotiropoulos T.E. 2005. In vitro propagation of the PR 204/84 (Prunuspersica $\times$ P. amygdalus) rootstock: Axillary shoot production and rhizogenesis. New Zealand Journal of Crop and Horticultural Science 33(1): 75-79. DOI: 10.1080/01140671.2005.9514333.

7. Glass A.D.M., Britto D.T., Kaiser B.N., Kinghorn J.R., Kronzucker H.J., Kumar A., et al. 2002. The regulation of nitrate and ammonium transport systems in plants. Journal of Experimental Botany 53(370):855-864. DOI: 10.1093/jexbot/53.370.855.

8. Lloyd G., McCown B. 1980. Commercially-feasible micropropagation of mountain laurel, Kalmia latifolia by use shoot-tip culture. International Plant Propagators' Society 30: 421-427.

9. Long L.E. 2003. Cherry training systems, selection and development.PNW 543, Corvallis, Oregon State University.

10. Long L.E., Kaiser C. 2010. Sweet cherry rootstocks for the Pacific Northwest.A Pacific Northwest Extension Publication, PNW 619, Oregon State University.

11. Mansseri-Lamrioui A., Louerguioui A., Bonaly J., Yakoub-Bougdal S., Allili N., Gana-Kebbouche S. 2011. Proliferation and rooting of wild cherry: The influence of cytokinin and auxin types and their concentration. African Journal of Biotechnology 10(43): 8613-8624. DOI: 10.5897/AJB11.450.

12. Murashige T., Skoog F. 1962. A revised medium for rapid growth and bioassays with tobacco tissue culture.PhysiologiaPlantarum 15(3): 473-497.

13. Nacheva L., Gercheva P. 2009. Micropropagation of 'Gisela 5' (cherry dwarf rootstock): The effect of the type and the concentration of the carbohydrates in the nutrient medium. ActaHorticulturae 825: 261-267. DOI:

10.17660/ActaHortic.2009.825.41.

14. Pierik R.L.M. 1997. In vitro culture of higher plants. Springer Science and Business Media, Springer, Dordrecht, the Netherlands. DOI: 10.1007/978-94- 011-5750-6. 
15. Quoirin M., Lepoivre P. 1977. Edude de milieu adaptes aux cultures in vitro de prunus. ActaHorticulturae 78: 437-442 (in French).

16. Reddy A.S.N. 2001. Calcium: Silver bullet in signaling. Plant Science 160(3): 381 404. DOI: 10.1016/S0168-9452(00)00386-1.

17. Ružić D., Sarić M., Cerović R., Ćulafić L. 2000. Relationship between the concentration of macroelements, their uptake and multiplication of cherry rootstock 'Gisela 5' in vitro. Plant Cell, Unauthenticated

18. Ružić D.V., Vujović T.I. 2008. The effects of cytokinin types and their concentration on in vitro multiplication of sweet cherry cv. 'Lapins' (Prunusavium L.).HortScience. 35: $12-21$.

19. Sarropoulou V., Dimassi-Theriou K., Therios I. 2013., In vitro rooting and biochemical parameters in the cherry rootstocks CAB-6P and 'Gisela 6' using Lmethionine. Turkish Journal of Agriculture and Forestry 37(6): 688-698. DOI: 10.3906/tar-1212-81.

20. Šiško M. 2011. In vitro propagation of 'Gisela 5' (Prunuscerasus $\times$ P. canescens). 